\title{
Singularities of Training Personnel in the Family Economics and Family Business at the Current Stage of Development of Market Relations
}

\author{
Vladimir Vladimirovich Glukhov ${ }^{1} \&$ Alexandr Vladimirovich Ponomarev ${ }^{2}$ \\ ${ }^{1}$ Economics, Far Eastern Federal University, Vladivostok, Russian Federation \\ ${ }^{2}$ Pedagogical Sciences, Ural Federal University, Ekaterinburg, Russian Federation \\ Correspondence: Vladimir Vladimirovich Glukhov, Economics, Far Eastern Federal University, 690950, \\ Vladivostok, 8 Sukhanova Street, Russian Federation. E-mail: gvv61@ fromru.com
}

\author{
Received: September 29, 2014 Accepted: October 29, 2014 Online Published: February 25, 2015 \\ doi:10.5539/ass.v11n6p198 URL: http://dx.doi.org/10.5539/ass.v11n6p198
}

\begin{abstract}
Transition of Russia to the development of market relations turned out to be an incentive motive for developing the basic concepts of the family economics and family business, a discovery of the opportunity for many Russian citizens to be engaged in entrepreneurship, which has formerly been inaccessible for them. The modern changes taking place in Russia and abroad raise new requirements for training the youths, for conscious active participation in various spheres of the socio-economic life of the society, in development of family businesses, and improvement of their efficiency. It should be noted that the problems of professional training of young people at higher education institutions as members of households in participation in the family business, formation of qualities of a future entrepreneur, and the entrepreneurial activity in the family business are actively considered and implemented in developed countries, while Russia does not virtually take part in this process. The main cause of failure in the family business is lack of competence, skills, and leadership qualities, as well as a set of competences needed for a successful business.
\end{abstract}

Keywords: family economy, family business, students, universities, the system of formation of competences, technology of knowledge development

\section{Introduction}

Transformation that took place in the political and socio-economic life of many countries in the late twentieth century, served as a basis for change in the life of the household, their attitude to the formation of private property, and the growing importance of the economic interests of the personality.

Transition of Russia to the development of market relations turned out to be an incentive motive for developing the basic concepts of the family economics and family business, a discovery of the opportunity for many Russian citizens to be engaged in entrepreneurship, which has formerly been inaccessible for them.

Formation and development of the family economy should not be generally seen as the total contribution of all members of the household to its budget, but as a collection of their personal finance, while the main role is played by the personal finance of that family member who is the principal earner-the breadwinner.

Financial relations arising between members of a household in the course of their daily activities are implemented in accordance with the accepted model of the budget management of the family, or with their personal relationships with each other.

Housekeeping thus cannot be considered as a homogeneous economic structure united by common interests.

Radaev V. proposed to consider a household in the narrower sense-as an occupation area, in which members of a family or an interfamily clan apply their labor to provide for their personal needs in the form of natural products and services (Radaev, 1997, p. 65).

\section{Methodology}

2.1 Interpretation and Content of the Family Economy Concept

Quite often, when studying the processes of provisioning the daily living activities of households, authors use 
different terminology describing the participation of all members of the family in them: family (home) economy, economy of a family (a household), organization of domestic labor, formation of the family capital, etc.

Participation in domestic labor creates special, non-transferable skills that increase the productivity of family households and represent the specific capital, which increases the benefits of each of the family members (Pollak, 1985).

However, we should keep distinct the organization and the running of a household, the family economy, and the family business-these are fundamentally different things.

In the economic literature, the interpretation and content of the family economy concept used by various authors is largely confined to the study:

- of models and methods of a household management and organizing activities for its maintenance;

- of forms of management of personal (family) finance and personal (family) budget;

- of the degree of involvement of family members in the daily living activities of a household, etc.

According to Kalabikhina I., the mechanism of interaction of the family and the economy and the degree of independence of households from the national economy have been treated differently by the Western and Soviet sciences, because there were two different models of socio-economic development: the market (capitalist) and non-market (socialist) models (Kalabikhina, 1995; Kalabikhina, 1998).

N. Zvereva treated family economy as a system of relations between its members differentiated according to their age and sex, in which system they enter into in the course of reproduction of their human capital. Family members use their income, property, and time in this process (Zvereva, 2006, p. 79).

The household economy is based on a fairly complex set of relationships between its members. These relationships are defined by differences in age, character traits, habits of people, different levels of their needs and income. However, normal development of a household is only possible if its members reach mutual understanding at making economic decisions (Kovalev, 2006).

An individual must be aware that he cannot get positive results of its financial activities if he does not comply with the general rules to ensure the effectiveness of the family economy as a whole.

The specificity of the household is that public production is linked with the personal one, and the economic production is linked with the social one, and the order of utilization of the available resources is determined as well as the rights and obligations of its members.

In this case, the subject of the "production" is not a single individual, but all members of the household running a joint household.

\subsection{Distribution of Economic Roles and Interests in a Household}

Distribution of economic roles and interests in a household and the very process of formation of financial relations between its members may vary depending on who is the "main breadwinner"-the main earner: one of the spouses or some of the other family members.

In the course of its daily living activities, almost every family faces the problem of choosing the optimal home load distribution among its members-organization of the family economy or the interfamilial financial management.

Indeed, while the economic interest in increasing one's personal wealth is the main driver of individual behavior, the main factor in the formation of financial relations in a household will be establishment of partnership relations with other family members.

In this case, the individual's personal finance will be contrasted with the contribution of other family members (in the form of domestic work) to provide for the daily living activities of the household.

What exactly each participant of a family economy will get as a result of the economic activity is determined by the form of financial relations existing in the household. Everyone makes his contribution to support the daily living activities of the household, someone contributes financial resources in the form of certain assets, another-his physical or mental labor corresponding to the market price, etc.

Consequently, the contribution of each member of the family economy is part of the labor of all family members aimed at preserving the achieved status of prosperity and effective use of received amenities. 


\subsection{Principles of the Family Economy}

Each family member takes his own part in the building of the family economy for gaining personal benefit, separation of personal property from the common family property, and achieving his own goals, which may be different from the general principles of running the household.

With the common goal-to contribute to support the common budget of the family, in which the individual lives, the personal benefit comes to the fore-the benefit in the formation of one's own independent personal finance, which one can dispose individually.

The general principle of justice in relation to the exchange of resources (financial, labor, etc.) within the household can be formulated as follows: each of the family members is provided with what he earns in the form of cash equivalent of goods or services in return for his contribution of resources to the family economy.

At that, each of the non-working members of the household receives the equivalent of the monetary contribution received by other members of the interfamilial exchange.

The principle of comparative advantage assumes that each family member has to expend efforts in the area, in which they bring the greatest return, where the opportunity cost of his choice is minimal (Martsinkevich \& Sobolev, 1995).

Such a principle of organization of the family economy can also be considered when one spouse is engaged in providing daily living activities for the household, and the second one pays directly to him/her a sum of money for rendering the "housing" services, rather than indirectly through financial resources transferred to the family budget for maintenance of the household.

The prerequisite for manifestation of economic contradictions within a household is the personal financial dependence of the unemployed or low-income members on the financial resources brought by others in the family budget.

Personal finance becomes the basic principle of economic independence as the main motive of making certain decisions expressing the power of those individuals who have the finance over those members of the household who do not.

The fact is that in this case, the household is driven not by the economy coupled with the national (monetary) assessment of options to use the scarce resources, but by what K. Polanyi called substantive economy associated with the human daily living activities. Human actions in such economy are determined by the motives that are significantly different from conventional profit or wealth maximization (Radaev, 1997, p. 68).

\section{Discussion and Debate}

\subsection{Family Business as a Form of Economic Relations}

In its turn, a family business is principles of organization of a family (private) business generating income for the household, when the owners of the manufacture are members of the same family (the same household) and jointly own the production factors.

Individual forms of economic relations emerging in the structure of a household may be reflected in the concept representing it as a homogeneous family business with one owner at the helm.

But in reality, this view does not reflect the economic processes and relationships relating to the allocation of financial resources within the family business, when the contribution of each member of the household in the production process is taken into account.

However, family business is not of personal nature, and is often the combined result of all the relatives (who do not need to live in the family) aimed at implementation of activities related to providing for the well-being of all members, taking into account the division of labor prevailing in the household.

A family business should aim, above all, the diligence, creativity, and thrift of all household members involved in joint production in order to develop the "sense of ownership" and responsibility for their business and the end result.

\subsection{Development of Family Business Abroad}

At the present stage of development of the society, the issues of support and development of family business in Russia and abroad become more and more urgent.

Exploring the oldest family companies in the world, we can identify their industry specialization. If we consider the history and duration of the existence of companies, we can notice that the record for the duration of the 
existence of companies belongs to companies with family ownership structure (O’Hara \& Mandel, 2002).

A comparative study of the dynamics of 500 companies conducted by Standard \& Poor's, have shown that a family business is ahead in its development and non-family companies in the long run the family business is often more successful than the non-family business (Anderson \& Reeb, 2003).

In family businesses, there is a high level of social responsibility; $77 \%$ named a higher degree of responsibility of the family business both at creation of jobs and in crises. The founders are ready to make more efforts than other companies to support staff (Volkov, 2013, p. 58).

In Western economies in the XIX-early XX centuries, family businesses always occupied a prominent place.

In the UK, family businesses (firms owned by families) number $75 \%$ of all firms in the country. English family businesses employ about half of the country population and produce about $50 \%$ of the total national product.

In EU countries, family firms account for $85 \%$, while in the United States- $90 \%$ of all enterprises. In Italy, family craft firms numbering 2-3 people provide for $18 \%$ of exports. Family businesses traditionally are engaged in retail, catering, farming, services (Barkhatova, 1999; Nikolaeva \& Rakhmanov, 2005).

Among European countries, Sweden boasts the largest number of family businesses-almost $60 \%$ of the working population are employed in family businesses (Gavrilina, 2012).

The Chaebols system allowed South Korea in the second half of the twentieth century to achieve optimal balance in the relations between the two pillars of the economic structure-the state and private business.

The whole world knows about thirty South Korean Chaebols; their main economic indicators are announced each year. For example, in 1998, together they accounted for $46 \%$ of all sales in South Korea in the industrial sector. The most famous Chaebols are: Samsung, LG, GS Group, Hyundai, SK Group, Daewoo, Lotte (Lavnikevich, 2012).

\subsection{Specificity of the Family Business}

Reznik, S. and V. Bobrov define family business as independent activity of citizens based on initiative and aimed at making profit based on the optimal use of the family capital, including physical, financial, and intellectual capital of the family members (Reznik \& Bobrov, 2003).

Family business does not implement any predetermined economic interests and intentions, but personal, individual goals of the household members aimed at improving their well-being; and at that, the market economy is a binding process, which is entered into by all of its members.

The individual making a decision on the establishment of his business or the use of his finance as investments in the selected sector of the economy is always uncertain about the long-term prospects for the consequences of his economic activity.

The founder of a family business tries primarily to improve the financial situation of his household, taking into account the relationships that develop between its members at the formation and use of common finance, while considering the family as an enterprise as a whole.

The difference of family economy from family business that produces goods and services consumed by other individuals and legal entities is that a household is both a producer and the end consumer of goods and services provided by the business.

Housekeeping provides the business with resources that are used by the latter as the production factors for goods and services and, at the same time, as the income factors. The exchange in the market of goods and services of a business for income earned from providing it with resources ends with transformation of part of the income into property in the form of resources and other property and non-property rights. At that, reproducing the main resource of the household-the labor, the household is the main productive force providing for the reproduction of the individual himself as a member of the household.

Talking about the family business owned by all members of the family, we could say that the main task of the currently existing economic relations within a household is to ensure the profitability of the family business, where the form and type of the business are not important, but steady income to the family budget from this business.

At that, the dependents-the household members (children, pensioners, etc.) are considered members of the family business, that is, its employees, even though they may be co-owners-to the extent, to which they can make their contribution to it, regardless of the fact whether they give a certain percentage of their income to the common budget or simply are dependents. 
One of the prerequisites for the involvement of the majority of households in the real sector of the economy is the increase in the range of services for both interfamilial and external (with respect to the household) use.

However, we should not deny that non-recognition of unpaid household labor forms dual approach in the society with regard to the formation of economic relations between the family members.

But what kind of classification should be followed in the event when all members of the family (household) produce goods and provide services only for internal, interfamilial consumption?

Self-organization of the household is a format of family labor and life, in which the family is committed to establish a rational (in terms of their interests) structure of consumption based on the real income, both monetary and in-kind one (Samsonov \& Shabanov, 1999, p. 46).

Here one can take advantage of the relationship: the market economy (production of goods for market sale)-home economy (production of goods for domestic consumption)-reciprocal exchange (exchange of products of own production), which provide the methodological basis for comparison of households (Barsukov, 2003, p. 22).

\section{Results}

\subsection{The Relevance of the Target Training of Youths in Family Business}

The modern changes taking place in Russia and abroad raise new requirements for training the youths to participate consciously and actively in various spheres of the socio-economic life of the society, to develop family businesses, and improve their efficiency, particularly in the circumstances of globalization and internationalization.

The transition to a post-industrial society leads to significant modification of national educational systems: on the one hand, to the side of their greater internationalization, and, on the other hand, towards greater individualization and increase of the role of non-standard educational practices (Klyucharev, Didenko, Latov, \& Latova, 2014, p. 18).

It should be noted that the problems of occupational guidance of young people, as members of households, for participation in family businesses, formation of qualities of a future entrepreneur, of the entrepreneurial activity in the family business are actively considered and implemented in developed countries, while Russia does virtually not take part in this process.

In Australia, according to the research by KPMG (April-May 2011, 658 family businesses in Australia responded), the factor "the competences of the family members engaged in the business» was the cause of conflicts (over 14\%) identified in the course of study of family business (Stewards, 2011).

The current development of the family business sector has once again found the "problem of talents", which affects the process of survival of the company and transfer of the family business: employing skilled staff (58\%) and retaining them $(46 \%)$ are the key concerns especially for companies planning a high level of growth (Family firm, 2012).

The reasons for failures in the family business in Belgium were said to be also personal problems of the founders: lack of competence and leadership qualities, as well as divorces and inheritance issues (Lambrech \& Wing Ting To, 2009).

According to the statement of Deputy Director of the Institute of Economic Policy Valery Tolstunov: "... In England, there are many publications on the subject, special schools where teachers thoroughly study with the successors their father's businesses models in relation to the overall market situation. In addition, there are many special conferences where business owners from around the world communicate and share experiences. In Russia, however, there is nothing except for two or three scanty translated books" (Mukovozov, 2011).

In this regard, it is important for higher education institutions to understand the necessity of students' participation in family businesses, to be aware of their real capabilities, to offer different teaching methods, and to be able to use them to include students in the entrepreneurial, commercial, and financial activities of the family.

\subsection{The Role of Universities in Training Personnel for Family Businesses}

Organization of a family business assumes first of all a certain level of social (human) capital, namely, the presence of a team. Studies on family business do not consider this issue in this angle: how to develop the structure of the senior management team for the launch of new projects in a family business taking into account the continuity and connection between generations? 
Research of the phenomenology and the process of forming a team in a business often find themselves between integration skills of the team members and the importance of proper building of relationships between the team members. Knowledge of the advantages and disadvantages of team-forming based on skills and based on organization of relations is particularly acute for the founders of a family business, since its specificity assumes the relationship to affect the managerial decision making process (Volkov, 2013, p. 93).

The rating of main requirements on the part of business owners to educational institutions are as follows: in the first place-the reputation of the institute, second-the academic standards / specialization, then international relations, and in the last place-the location.

For example, the studies of small and medium-sized businesses in Russia showed that $31.3 \%$ of responders rely on the higher education institutions in terms of education of values necessary to conduct a family business (Volkov, 2012).

The conducted poll of relatives of students about how they would react if their successors indicated entrepreneurial activeness in the family business showed that more than $85 \%$ of parents would react positively if their children built entrepreneurial career, with $45.5 \%$ responding very positively. But how important is it for the students themselves what their parents say about their future careers? In $84.9 \%$ of cases, the parents' opinion is very important, $44.4 \%$ of students indicate that this opinion is extremely important, the average score is about 5.87. Questions of succession are often associated with the barriers at entering into the family business; in the process of studies, the significance of barriers was assessed by students (Volkov, 2013, pp. 79-80).

The results of studies conducted in Germany and the UK show that the most preferred is the joining of students studying business and economics to the family business, Table 1, (Zelweger \& Sieger, 2012).

Table 1. Preferences of students in the choice of subjects, in preparation for the family business

\begin{tabular}{llll}
\hline № & Subject & Number of students, \% & Note \\
\hline \multirow{2}{*}{ Social sciences } & 4,1 & potential successors (soon) \\
& & 8,6 & potential successors (in 5 years) \\
2 & Natural sciences & 5,1 & potential successors (soon) \\
& & 11,5 & potential successors (in 5 years) \\
3 & Business and economics & 9,5 & potential successors (soon) \\
& & 15,5 & potential successors (in 5 years) \\
\hline
\end{tabular}

Changes in public, social, and economic life take place rather quickly, because without the constant updating of knowledge, it becomes very difficult to work. Currently, the demand for business education increases. And both graduates, and managers, and executives at all levels want to pass it. Business education helps not only acquire new communications, but also strengthen the competitiveness of a business, update and expand the range of professional activities.

\subsection{The Directions of Development of Business Education in Russia}

In our view, the fundamental strategic directions for the development of the business education system are:

1) Overcoming the narrow specialization of professional education. Business education promotes professional development of specialists, unlocks their human potential, determines the possibility of obtaining a degree in an allied science and the nature of the educational activity.

2) Drawing an individual learning path (the individual approach). Unlike traditional systems, business education allows constructing a flexible learning path for each individual student and mastering it, referring to the external and internal information environment in the most convenient and comfortable mode for this purpose. The student himself determines what educational program to choose. The block concept of learning is widely used at that.

3) Ensuring continuous learning-the lifelong learning-based on the new needs of a human that are relevant to the requirements of internationalization and globalization of the economy, his professional achievements and demands, versatile content and different degrees of assimilation.

4) Organization of new forms and methods of teaching based on the latest achievements in the field of the computer science. Today, business education is inconceivable without advanced interactive technologies (remote learning, case studies, the Internet, video conferencing, etc.), which not only facilitate learning, but also improve 
the quality of educational programs.

5) Increased motivation to learning is also emphasized. Business education has an impact on the social status of a person, his material well-being and career growth.

One of the lines of business education should be programs of training in the family business.

Entrepreneurial activity among young people occurs when the necessary level of professional and general cultural competencies is formed.

In this regard, the role of higher education institutions should become more visible in the implementation of education of the family business members.

It is essential for the training and educational process at a higher educational institution to contribute to familiarizing students with the family business, and the family, in turn, to involve them in the active development of the competences required for the development of individual entrepreneurial skills.

According to the study of 52 employers representing 23 leading Russian companies, the following set of skills required for learning at a higher educational institution, including for the successful running of the family business, has been identified:

1) to master the technology of the main types of business communication;

2) to be proficient in cooperating, taking part in teamwork, supporting command decisions, strengthening and enhancing the "team spirit";

3) to have a high level of self-organization, to be active, to transform the reality to one's own interests, to strive for self-assertion and self-fulfillment;

4) to be able to plan and coordinate own and others' actions to achieve the goal;

5) to understand the main lines of development and innovative activity of the enterprise without prejudice to the environment;

6) to possess the knowledge of the culturololgical principles of family and social relations, public events, and traditions;

7) to understand the importance of one's functions and the degree of one's responsibility as a personality in a society, focused on the improvement and development of the society based on the principles of humanism, freedom, and democracy (Ponomarev, 2009).

4.4 Modernization of the Educational Paths of Higher Educational Institutions for Target Training of Personnel for the Family Business

In the learning process of higher educational institutions, special lectures and practical classes should be organized within the framework of special courses "Economics of Entrepreneurship", "Basic Concepts of Family Business in Russia", "Models of Effective Management of a System Business", "Household Economy", "Family Economy", "Finance of Households"; non-formal education programs should be developed, such as "Educator", "The Art of Life Management" etc.

As part of the research and innovation activities of higher educational institutions, involvement of students in the activity of small innovative enterprises with the participation of universities was arranged.

Another important factor of preparation for working in a family business is the development and implementation of educational practices in programs of higher educational institutions of forming the necessary personal qualities and relevant competencies.

As part of the students' associations of higher educational institutions, it is necessary to engage students in a variety of activities, both within the educational process, and during extracurricular activities aimed at fostering their entrepreneurial activity.

A list of these events can vary and include "Innovative Diving" (development of innovative entrepreneurship), "PredpriniManiya: Start Your Own Business" (Competition of students' business projects), "Career Path" (a series of master classes with navigation on the family business), etc.

The most essential to prepare students to participate in the family business is their inclusion in the real production relations, production and economic and administrative activity of business projects implemented with the participation of families whose interests they represent (at the time of study at the university).

A higher educational institution could also implement various projects that would enable participants of family 
businesses to pass internship and practice in another private or family company, and possibly in a different region, country or in a particular segment of the economy.

At the development and implementation of effective technology of personnel training for family businesses, the development of partnership between the higher educational institution and the real economy sector, it is necessary to create opportunities for high quality education and development of students, and to strengthen the family values.

Studies carried out in 2011-2013 among graduates of UrFU in the field of the future cooperation capacity showed that the most significant values for them are health, family, and education and development of children (Kondratkov, Osipchukova, \& Ponomarev, 2014).

\section{Conclusion}

In Russia, the family business has not yet started actively developing, as well as the targeted personnel training for it, which is evidenced by objective and subjective factors. Social transformations of the Russian society that occurred in the twentieth century destroyed the traditions of the Russian business that had been formed for a long time.

The majority of Russian entrepreneurs belong to the new generation who have not quite think about how to transfer their assets by inheritance, because in the first place they face the problem of survival at all.

Formation and further development of the system of targeted training of personnel for the family business, determination of the needs, identification of the most common standard approaches, implementation of ambitious and prospective business projects for the family economy are ones of the most important and urgent objectives of higher educational institutions.

For more effective training of personnel for the family business, it is necessary to provide comprehensive studies to both determine the goal-setting of the formed mentality of Russian entrepreneurs and provide comprehensive targeted training of such personnel by education institutions of various profiles with account of the demands of the educational services consumers.

The targeted training of personnel for the seed business in modern Russia is only at the very beginning of its formation, and the experience of developed countries in such matters could be very useful.

The presence in the higher educational institutions of a flexible system of business education programs including those specialized in family business management as well as the presence of special educational paths will allow prompt training of youths in successful conduct of a family business.

\section{References}

Anderson, R. C., \& Reeb, D. M. (2003). Founding family ownership and firm performance: Evidence from the S\&P 500. Journal of Finance, 58, 1301-1326. http://dx.doi.org/10.1111/1540-6261.00567

Barkhatova, N. M. (1999). A family business and family business. IVF National Economic Journal, 2, 127-150.

Barsukova, S. Y. (2003). The nature and function of home economics, methods of measurement of household labor. Sociological Research, 12, 21-31.

Family firm: A resilient model for the 21st century. PwC Family Business Survey. (2012, October 24). Retrieved September 17, 2014, from http://www.pwc.com/en_M1/m1/advisory/documents/family-businesssurvey-2012.pdf

Gavrilina, T. (2012). Family business: When the family-the most reliable partner. Retrieved September 15, 2014, from http://turboseo.net.ua/blogue/family_business.htm

Kalabikhina, I. E. (1995). Some aspects of the theoretical analysis of the household. Vestnik MGU, 6, Economics, $5,28-40$.

Kalabikhina, I. E. (1998). Gender reproduction of human capital. Vestnik MGU, 6, Economics, 5, 43-59.

Klyucharev, G. A., Didenko, D. V., Latov, Y. V., \& Latova, N. V. (2014). Continuing education-a stimulus of human development and a factor of social and economic inequalities. Moscow: TsSPiM.

Kondratkov, P. V., Osipchukova, E. V., \& Ponomarev, A. V. (2014). Organization of the alumni of the university: Regulatory support: a collection of standard documents. Ekaterinburg: Ural Federal University.

Kovalev, V. V. (2006). Finance. Textbook (2nd ed. Revised. and ext.). Moscow: TC Welby, Acad Prospectus.

Lambrech, J., \& Wing Ting To. (2009). Falingsoorzaken bij zelfstandigen en KMO”s. Een kwantitatieve en 
kwanlitatieve analyse, project conducted on behalf of Lideraal Verbond voor Zelfstandigen.

Lavnikevich, D. (2012). South Korea: By Chaebol. Retrieved September 15, 2014, from http://economics.bel.biz/articles/yuzhnaya_koreya_putem_chebolya/

Marcinkiewicz, V. I., \& Sobolev, I. V. (1995). The economy of humans. Moscow: Aspect Press.

Mukovozov, O. (2011). Family business in Russia. Information-analytical reference. Retrieved September 17, 2014, from http://www.slideshare.net/mobile/omukovozov/15012011-27247337

Nikolaeva, L. A., \& Rakhmanov, M. S. (2005). The economy of the household and the surrounding society. Vladivostok: Izd VSUES.

O'Hara, W. T., \& Mandel, P. (2002). The world's oldest family companies. Family Business Magazine, 37-49. Retrieved September 18, 2014, from http://familybusinessmagazine.com/index.php?/issue/spring_2002

Pollak, R. A. (1985). A Transactional Cost Approach to Families and Households. Journal of Economic Literature, 23(2), 581-605.

Ponomarev, A. V. (2009). Socio-educational function of the university in the education of modern specialist. Moscow: The IKAR Publishing House.

Radaev, V. V. (1997). The man in the household. Sociological Research, 4, 64-72.

Reznik, S. D., \& Bobrov, V. A. (2003). Management of the family economy (2nd ed., rev. and ext.). Moscow: CJSC "Publishing house" Economy."

Samsonov, V. B., \& Shabanov, V. L. (1999). Self-organization of agriculture. Sociological Research, 3, 46-51.

Stewards: Moving forward, moving onward. KPMG and Family Business Australia's Family Business Survey. (2011). Retrieved September 12, 2014, from http://www.kpmg.com/AU/en/IssuesAndInsights/Articles Publications/documents/family-business-survey-2011.pdf

Volkov, D. A. (2012). Family business in Russia: Socio-economic aspects of management. Moscow: Creative Economy.

Volkov, D. A. (2013). Continuity and specificity control the family business. Moscow: Creative Economy.

Zelweger, T., \& Sieger, P. (2012). Coming home or breaking free\& Career choice intentions of the next generation in family business. Ernst \& Young.

Zvereva, N. V. (2006). Economics of the family and children. Vestnik MGU, 6, Economics, 2, 79-95.

\section{Copyrights}

Copyright for this article is retained by the author(s), with first publication rights granted to the journal.

This is an open-access article distributed under the terms and conditions of the Creative Commons Attribution license (http://creativecommons.org/licenses/by/3.0/). 